\title{
LIBRARIANS AND BOOK COLLECTORS: FRIENDS AND FOES ${ }^{\top}$
}

\author{
BY WILLIAM P. BARLOW, JR.
}

Mr. Barlow is a collector of rare books and fine printing who lives in Oakland, California.

$\mathrm{T}$

HE relationship between book collectors and librarians has always been an ambivilent one: cordial but suspicious, suspicious but deferential, deferential but competitive. A symbiotic relationship, I suppose, except that symbiosis implies the survival of both species. Book collectors die (or lose interest in collecting, which is much the same thing), while librarians metamorphose indefinitely and even thrive by picking over the collector's earthly remains, the collections the deceased or disinterested collectors have left behind. Is it any wonder that the book collector would approach his relationship with librarians with the same anxiety with which the male black widow spider approaches sex? The librarian, on the other hand, has his own anxieties. The collector is a formidable foe in the auction room and seems to have a better rapport with book dealers. And the librarian-unlike the collector-must worry that his collection is being eaten away by theft, mutilation and even, on occasion, use.

The first of the conflicts between collectors and librarians to come to mind is competition. Competition, as we all know, is the foundation of the American way of life. And the American way of dealing with competition is to complain about it. But is the complaining really justified? Librarians complain that collectors, all of whom are rich and have a disregard for the value of money, not only are able to outbid libraries for books and manuscripts which ought to be made available to scholars but, in addition, drive up the market to outrageous levels even on the items they do not buy. Collectors, on the other hand, complain that they are no match for libraries, with their multi-million dollar budgets.

There have been and still are collectors who could significantly influence the market for books, but they are not the average collector. Don Dickinson, writing in the current issue of The Book Collector, describes some of Henry E. Huntington's purchases. Between the acquisition of the entire library of Elihu Dwight Church in I9I I for slightly over

I This paper was delivered as the Louis Fagures Bishop III Lecture at the Rutgers University Libraries on I6 November, 1988. 
$\$ \mathrm{I}, 000,000$ and the purchase of the Bridgewater House library for a similar sum in 1916 , there were the auctions of the Hoe and Huth libraries and en bloc purchases of Beverly Chew's early English plays $(\$ 230,000)$, and 25 Caxtons from the Duke of Devonshire $(\$ 750,000)$, and the entire American section of the Britwell Court library the day before the public auction ( $\$ 300,000$ or so). Certainly purchases like these influenced the market. Belle da Costa Greene, J. P. Morgan's librarian, complained: "The prices that are being paid for rare books at the Hoe sale . . . are perfectly ridiculous. They are more than ridiculous - they are most harmful. They establish a dangerous precedent." I am not sure the Hoe heirs would have agreed. Today the several million Huntington spent in that five year period would not come close to acquiring his vellum copy of the Gutenberg Bible or the Ellesmere Chaucer, but there has been a bit of inflation in the past 70 years.

Librarians, too, have had their day with the market place. In 1959 The Book Collector repeated this not-too-exaggerated claim from an inside source at the University of Texas: "With the resources now at our disposal we expect to disrupt all markets the world around in our search for significant material, particularly from I 700 onwards." The magazine then lamented: ". . . if . . . the oil money in Texas starts buying books, the rest of us will have only to stand on the side and watch them go by."

Does all this represent good old American red-blooded competitionthe kind of entreprenurial spirit and calculated risk that enabled the bookseller George D. Smith to brag that he had broken the English booksellers' 'ring' at the Huth sale-or does it represent that evil cancer of commerce: unfair competition? On the whole, competition in the book world has been just that. Compared with the way industrial and financial giants like J. P. Morgan, Henry E. Huntington and Henry Clay Folger amassed their fortunes, the way they spent them seems relatively benign. Nevertheless, Worthington Chauncey Ford, then distinguished librarian of the Massachusetts Historical Society, was not entirely jesting when he wrote, "My general theory is that every book collector is more or less a pirate."

But the most excessive competitive threats to libraries have not been from collectors but rather from other libraries. In the I960s it seemed that every university and college in America felt the need to have a special collections division and to fill that division's shelves with rare books. The fact that these collections were designed more to benefit image than scholarship and that the books seemed always to be the same, did not help. On their own, libraries created intense and expensive competition in several 
areas. With the austerity of the I970s, many of these special collection rooms were closed and many of the rest exist with no acquisition budget. Today the major research libraries - especially those in the same part of the country-have 'understandings' that avoid competition for the same material.

The concern of book collectors over the heavy-handed use of libraries' multi-million dollar budgets is exaggerated. If we subtract the library's costs of cataloguing, housing, maintaining and delivering books to their scholarly clientele from their purported multi-million dollar budgets, we get down to the book acquisition budget at a fraction of the whole. And even this smaller amount can hardly be compared directly to the budget of the private collector. The acquisition policies of a library, after all, are dictated by the demands of vocal professors and the need to maintain existing strengths. In terms of its purchasing power in any one of the many areas it must support, the library can hardly be regarded as having monopolistic strength.

The collector, in fact, enjoys several advantages over the library. One is the simple ability to tailor his collection to his personal taste and to his purse. Another is the speed of his decision making process. And often overlooked is the strong preference most book dealers show for sales to private collectors. This has sometimes been attributed to the slow-paying and red-tape-laden policies of libraries, but the underlying factor is the book seller's knowledge that a book sold to a collector may yet come back to market to provide a second profit, while a book sold to a library is gone forever.

This brings us to the next source of irritation between collectors and librarians: the library as the bottomless pit-or perhaps in today's more favored space-oriented terminology: the library as the black hole of books. While collectors constantly talk about the "good old days" of book collecting-by which they mean low prices and wonderful books to buythey don't often say exactly why these wonderful books are no longer to be found. Brayton Ives wrote in the preface to his I 89I sale (he lived to I 9 I 4 and a second library was sold after his death): "The dispersion of several of the finest libraries in England gave unexpected and most favorable opportunities to secure books of this description [early printed books]. It is not in the range of probability that collectors will ever again have such facilities in this direction as were given by the sale of the Sunderland, Hamilton Palace, Beckford, Syston Park and Wodhull Libraries." Well, where are all the books from Sunderland, Hamilton Palace, et al? Certainly to the extent that Ives bought these books they were again 
made available to the collecting public. Clearly, although never directly stated, the "black hole" is to blame. This is the ultimate revenge of the impoverished librarian who must sit on the sidelines while titans of industry battle in the salesrooms for a desired volume. Not only will the few crumbs the libraries can afford to buy be forever withdrawn from the collector's market, but sooner or later even the great prizes beyond the librarian's means will come his way: by gift, by bequest, or by a combination of gift and purchase. So the librarian ultimately has his revenge, and the irony is that it is the collector who has provided it.

What is it that induces a collector to give his library to an institution? Not all collectors, by any means, have been so inclined. Beverly Chew, writing in the foreword to the Hoe sale catalogue recalled:

Mr. Hoe once told me, on his return from Europe, of a visit he had made to one of the great Libraries, and of his feelings of surprise and disgust at the utter lack of reverence and appreciation he found as shown in the want of care given to the great monuments of printing. The catalogue of this library was rich in the masterpieces of the early printers, and when he asked for them, volume after volume was brought to him covered with dust, with leaves stained and bindings broken and in every way proclaiming the effects of indifference and neglect. 'This,' he said, 'confirms me in the conviction that those who love books should have them in custody and will take the best care of them.' 'If the great collections of the past had not been sold where would I have found my books?' To have kept unbroken the great library Mr. Hoe collected would no doubt have been a noble monument to his memory, but I am convinced that the remark I have quoted truly states his reason for the direction he gave in his will for the sale of his wonderful collections. He loved his books and wished them to pass after his death to those who would continue to cherish and care for them, and that they in their turn should transmit them to the booklovers of the future.

Another example, quoted for many years on the back of Anderson Galleries auction catalogues, is a translation from the will of Edmond de Goncourt:

My wish is that my Drawings, my Prints, my Curiosities, my Books-in a word, these things of art which have been the joy of my life--shall not be consigned to the cold tomb of a museum, and subjected to the stupid glance of the careless passer-by; but I require that they shall all be dispersed under the hammer of the Auctioneer, so that the pleasure which the acquiring of each one of them has given me shall be given again, in each case, to some inheritor of my own tastes. 
I will return a little later to de Goncourt's image of the "cold tomb of a museum."

Some collectors have adopted a middle approach by giving parts of a collection to an institution and selling the remainder. This makes sense if some portion of the collection clearly deserves to be kept together. Another intermediate step is one tried early on by George Brinley, whose famous collection of Americana was sold at the end of the last century. Brinley arranged for $\$ 25,000$ in credit to be spread among five different libraries for purchases from his collection. This not only made books available to those who most needed them, but not incidentally, stimulated bidding on the whole. Joseph J. Cooke, a few years later, decided that $\$ 50,000$ and Io libraries would be twice as good a plan, but he did not have nearly so valuable a library, and all that was stimulated was a bidding war to use up the credits. The auction only realized about $\$ 70$, 000 .

Nevertheless, over the years a substantial percentage of the important libraries in this country have gone to institutions. Of the 75 distinguished collectors whose biographies appear in Grolier 75 about half gave their collections to libraries. Some of the greatest collectors in that list (Hawkins, Walter, Morgan, Huntington and Clark) created their own institutions, and the gifts of Thacher, Berg, Clements, Goodhart and Widener were no less important to the existing institutions which received them. There are any number of reasons why a collection is given away. Chew mentioned the motive of creating a monument to the collector, but it is fair to say that the Hoe sale catalogue is an equally impressive and very well known monument, and every time a collector finds Hoe's little red morocco bookplate in a volume his memory is recalled. More often the collector is impelled by the desire to keep a collection together. This is particularly true with highly specialized collections which have much greater value as a unit than do the individual books. And then there are the usual motives familiar to every university development director: the old school ties, the feeling of well-being, the honor and prestige, and, finally, the tax deduction.

Not all of these enticements by libraries work, however. A particularly painful example is to be found in the pages of the Phillipps Studies. Sir Thomas Phillipps' collections of manuscripts and books was surely one of the most important ever assembled, and its dispersal, after more than IoO years, is still not complete. Prior to his death, Phillipps made several stabs at giving his collection away. In one of his wills he bequeathed his manuscripts to the British Museum with the expressed wish that the nation might pay off his not inconsiderable debts in return. At other times his 
goal seemed to be the establishment of a Phillipps library in Wales. At one point, Phillipps was made a Trustee of the British Museum, a not infrequently employed tactic today. But this goodwill gesture only served to give the irrascible peer grounds to decry the 'mismanagement' of that institution.

Phillipps' negotiations with Oxford involved complicated discussions of suitable separate space, but ultimately foundered on his proposal that he be made Principal Librarian at Bodley, with the existing librarian moving to his assistant. When this proposal did not get a response, Phillipps rather angrily asked why, and the librarian, H. O. Coxe, diplomatically under the circumstances, replied, "My own vanity did not, I assure you, lead me to pass in silence your remarks about the headship of this place. I simply thought you were in joke. The idea of a man of your rank and fortune offering himself for such a post, was what I could not entertain for a moment as a serious proposition."

The librarian of any major research institution could tell similar stories. Demands for restrictions are common-perhaps not as impossible as Phillipps' desires to prevent his books from being used by Roman Catholics or by his hated son-in-law-but still restrictions: a separate room, a printed catalogue, limitations on use, and, curiously, in view of the collector's presumed attitude which has precipitated this discussion, a ban on the sale or other disposition of anything from the collection. With a great library being offered, it is difficult for any librarian to turn down these restrictions, but one nonetheless wonders how many private libraries that go to auction only do so because no library will accept the collector's conditions for a gift.

This brings us to the final source of complaint between collectors and librarians that I will discuss: the accumulation of duplicates in an institution. This accumulation is inevitable and poses great difficulties for everyone concerned. One point of view is made in this 1962 article from The Book Collector, a magazine whose title ought to announce its position. Aside from being further Texas-bashing, it makes an uncomfortable point:

Considering that the University of Texas Library is the pacemaker in the relentless race, it is somewhat paradoxical that the Humanities Research Center at Austin proposes to award three annual prizes, presented by several friends of the Library, for 'student book collections.' (By an oddly un-Texan ruling, 'size and expense' will not be taken into consideration.) We can hardly suppose that the Center's recto is unaware of what its verso is doing; 
but, much as we applaud any attempt to encourage the young collector, we cannot help wondering how the offer of a few crumbs from the rich man's table can be reconciled with the multiplication on his own shelves of invariant copies of the same book. The James Joyce collection at Texas is a case in point. According to the University's Library Chronicle, it contains inter alia' 9 of the 1000 copies of the first edition (February 1922 printing) of Ulysses . . f five copies of the first edition of Chamber Music . . . and six copies of the first edition ( 1 927) of Pomes Penyeach.' Does Texas really need all these copies? And, if so, for what purpose? The private collector will grudgingly admit that Texas needs its eighteen copies of the first edition of Poe's Tales (I 845), if only to enable the ingenious Dr Todd to tabulate, their variant states and issues, but what, he may well ask, does Texas want with nine 'firsts' of Ulysses - three of them copies of the impression on Dutch handmade paper intended for bibliophiles? . . An official statement of policy . . . would be welcome, for it seems as if Texas, by handing out money to buy books with one hand and taking away the books with the other, were going out of its way to discourage and deny the private collector.

Libraries have, of course, been disposing of duplicates for years. Often these have been quiet transactions involving individual books. Many of these are exchanges through book dealers for more desirable material. The exchange frequently is used not only to keep a transaction as quiet as possible but also to frustrate the requirements of many universities that the proceeds from direct sales of assets must go into university rather than into library coffers. The recent appearance of a number of Library of Congress Copyright copies of twentieth century books is evidence of this sort of activity. After all, as a rule, there are two Copyright copies.

Sales of duplicates at auction have also been going on for generations. The sale of duplicates from the Königliche Landes-Bibliothek of Dresden ran from I 775 to I 777 and contained more than 33,000 lots. These sales followed by less than Io years the gifts to that institution of two of the most immense private libraries in history: the Bunau and Bruhl collections, together totalling more than 100,000 volumes. Sales of duplicates of the run of the mill books from libraries generally occasion very little comment, but they often present great difficulties for the libraries involved. I can recall, as an undergraduate at the University of California, noting that the library had three copies of the Ratdolt Euclid of I482, which has always been an expensive book. One of the copies had been in the library for decades and was, as a result, stamped and perforated. A second copy had not been so defaced but had suffered from the binder's 
knife in the previous century and moreover was restricted from sale by the terms of the bequest. The third copy was in the John Henry Nash collection, unrestricted as to sale, but part of a unified collection and by far the nicest copy. Which one should be sold? The one you would like to sell but legally can't; the one you can sell but whose value has been severely reduced; or your best copy? Or do you just sit around with all three copies?

A change in the collector's attitude toward sales by libraries began to develop in the last generation. An early battle-cry was sounded by John Hayward in The Book Collector over the Louis H. Silver collection-a collection largely of 'high spots'. This collection was bought en bloc by the Newberry Library and about a third of the items acquired were subsequently resold at Sotheby's. Hayward remarked:

While all collectors, dealers, and libraries will welcome Newberry's decision to get rid of what they consider superfluous to their needs, and like Folger, Indiana, and other institutional libraries who have sold their duplicates in recent years, give others an opportunity of acquiring books they have long sought in vain, it does seem very odd that much of the material now to be thrown on the market should be the very stuff of which great research libraries (and Newberry justly pride themselves on being one of the foremost) are made. It is understandable that Newberry, after blowing (or is it blueing) a sizeable chunk of their capital reserves should need to launch the first fund-raising drive in their 78 years of existence and no one could criticize their decision to turn into cash such 'collectors' pieces' as a Kilmarnock Burns in the original wrappers or an Evelina uncut in its original boards; but how, one asks in bewilderment, can they afford to sell from a collection purchased in order to fill specific gaps and generally to increase their research resources, manuscripts and autograph letters which, being unique, cannot conceivably be classed as 'duplicates' and rare printed books which may be loosely described as duplicates but which no experienced bibliographer could say were 'surplus' to his needs-the Mainz Cicero, for example, with its mixed leaves, or the Block Books with the possible inferences to be made from the condition of the blocks? Maybe the answer is simply that they could not afford not to, or in other words that they had to pay more than they could really afford for something they did not altogether want.

By I 98 I, when the John Carter Brown Library decided to sell some illuminated manuscripts, librarians were much more concerned about public relations. Not only was there a full explanation of the decisions 
made and the reasons for them, but the library even sponsored a conference on the subject which had, by then, become known as 'deaccession.' This sale passed the muster of The Book Collector commentator, who described the manuscripts sold as "a splendid if irrelevant appendage now released to further the Library's main purpose, the preservation and study of material relating to America."

If the library world learned anything from John Carter Brown it should have been the need for adequate public relations. Most recently ignoring this lesson was the University of Manchester. An article in The Book Collector (once again) announces its position in its title "The Rape of the Rylands." The opening paragraph of a I 3-page article succinctly states the concern:

The University of Manchester has now had its way with its library: it has sold almost a hundred of its best books for a relatively small sum. It has destroyed the integrity of a great part of the bibliothecal wealth of this country. It has also alienated public opinion, and with it any hope of raising the funds from other sources to support the Institution whose needs were the nominal cause of the sale. Finally, it has opened the door, unless perhaps the almost unanimous outcry has shut it again, to any other attempt to meet the needs of the present by selling the heritage of the past.

In their defense the powers at Manchester made several arguments, but the key was its determination that the Rylands library, in particular, be rescued from its moribund state. As The Book Collector summarized, "over and over again, the words 'museum' and 'mausoleum' recur, apparently as synonomous for all that is bad." You may recall that Edmond de Goncourt did not want his books "consigned to the cold tomb of a museum." Now when Manchester declares itself free of that awful image, it is criticized for doing so.

Manchester's attempt to characterize its image as that of a museum and a museum as 'bad' is unfair. Must a book be used to be worthwhile? With the exhaustive work of Charlton Hinman and the publication of the Norton facsimile of the First Folio of Shakespeare, it could be argued that there is no further scholarly value to a copy of the First Folio itself. Bear in mind I only said it could be argued; I will not argue that myself. Should First Folios, then, be put away on back shelves or even sold to sentimental collectors? There seems no harm-and indeed much good-in putting such books on display for the public who will never have a chance to handle them. If this is the function of a museum, is it not still a beneficial one? It is as if a Greek amphora is of no value if it doesn't hold wine. If I 
were a museum director I would be insulted to hear that intelligent public display was an inferior use of an object. I have not, by the way, made any attempt to get the reactions of directors of mausoleums.

The perceived villainy at Manchester was the harm done to the integrity of two great collections of the past. I had suggested this same point in a talk given nearly five years ago at the Library of Congress. I can hardly claim that my modest suggestion at that time had anything to do with the furor over the Manchester decision, but I will repeat it here anyway:

Where a collection or a unified part of it passes directly into an institution, I would like to suggest the value of maintaining the integrity of the collection. That does not mean that the collection must be kept as a unit. This is impractical for all but the most significant collections. But listings of these collecting units can certainly be maintained. Decisions on whether to place items in the stacks or retain them in special collections can take the integrity of a collection into account as can decisions on the disposition of duplicates.

The collection itself is the mirror of the collector, and although this image may be much less important to the institutional library than the books themselves, it is not so unimportant as to be disregarded and irretrievably lost.

The point is not that libraries are damned if they retain duplicates and damned if they sell them but rather that any sale, disposition or even the breaking up within a single library of important collections deserves thought, consultation and effective public relations. Librarians have always known that neglect of books in their care will serve, as pointed out by Robert Hoe, to turn collectors and their collections away. Now they should know that the mistreatment of the integrity of what the collector has formed may well have the same effect.

What a librarian does best is preserving and making books available to scholars and collectors. What a collector does best is collecting. As Randolph Greenfield Adams said: "If he [the collector] does nothing but make the collection, he has accomplished a life work. The exploration of the collection can safely be left to those less courageous individuals who write books from the sources to be found in the collector's library. I call them 'less courageous' because they take no chances, they do not sacrifice all other earthly treasures in the building up of a library which they are privileged to enjoy. Moreover they are in most cases people with good analytic minds who can best use the collection - but then many people have that kind of mind. The mind of the collector is essentially synthetic and imaginative." 
And the collector can, in some instances, shape scholarship. James Lowry Clifford, one of the great Johnson scholars of this century, claimed that book and manuscript collectors were responsible for the revival of interest in Samuel Johnson. In his Summary of Johnsonian Studies he wrote:

The collectors . . . have been of major importance in the development of the new Johnsonian approach. The most celebrated of the earlier twentieth century-R. B. Adam and A. Edward Newton-not only carried on the traditional interest in every person and thing connected with the Johnson circle, but increasingly directed attention to Johnson's own works. Moreover, from the start, both men showed a commendable desire to share their treasures, to make them available to serious research scholars.

It is easy to see why collectors are such useful friends to librarians and scholars. And librarians can, and should be, useful friends to collectors, as sources of information, as encouragers of collecting, and as a rule very good company. Why, then, should they not be friends? May I suggest that perhaps it is the book sellers who are stirring up all the trouble? But that is another paper. 